\title{
A Proteomic Study on Donkey Milk
}

Silvia Vincenzetti ${ }^{1 *}$, Adolfo Amici ${ }^{2}$, Stefania Pucciarelli ${ }^{2}$, Alberto Vita ${ }^{2}$, Daniela Micozzi ${ }^{3}$, Francesco M Carpi ${ }^{3}$, Valeria Polzonetti ${ }^{3}$, Paolo Natalini ${ }^{3}$ and Paolo Polidori ${ }^{4}$

${ }^{1}$ Veterinary School of Medical Sciences, University of Camerino, Italy

${ }^{2}$ Department of Molecular Pathology and Innovative Therapies, Marche Polytechnic University, Italy

${ }^{3}$ School of Biosciences and Biotechnology, University of Camerino, Italy

${ }^{4}$ School of Pharmaceutical Sciences and Health Products, University of Camerino, Italy

\begin{abstract}
In children with Cow Milk Protein Allergy (CMPA), when it is not possible to breast feed or to use cow milk, the clinical use of donkey milk is considered since several studies have demonstrated the high similarity of donkey milk compared to human milk.

An analysis was performed on donkey milk protein profile by two-dimensional electrophoresis (2-DE) followed by $\mathrm{N}$-terminal sequencing in order to give a panoramic view of the proteins that are present in donkey milk. Furthermore, the interest was focused on the casein fractions and on their phosphorylation degree that may influence the calcium binding ability of caseins. At this purpose experiments on donkey milk casein dephosphorylation have been performed and the dephosphorylated casein fractions have been identified after 2-DE analysis followed by $\mathrm{N}$-terminal sequencing. Among caseins were found mainly as 1 - and $\beta$-caseins that showed a considerable heterogeneity due to variable degree of phosphorylation and to the presence of genetic variants. Finally, a quantitative determination of some antimicrobial proteins, such as lactoferrin and lactoperoxidase, that could be able to stimulate the development of the neonatal intestine, was performed in donkey milk, with the results being $0.080 \pm 0.0035 \mathrm{~g} / \mathrm{L}$ and $0.11 \pm 0.027 \mathrm{mg} / \mathrm{L}$, respectively. From the obtained data is evinced that human and donkey milk contain considerable amounts of lysozyme and lactoferrin but lactoperoxidase is present only in small amounts, confirming the high similarity between donkey and human milk. The present study on donkey milk proteins may be useful to assess the nutritional characteristics of this milk that is used to feed children affected by CMPA, but also may open the possibility of utilizing donkey milk in the general population to benefit subjects with CMPA, such as adults and the elderly.
\end{abstract}

Keywords: Donkey milk; Proteomic; Lactoferrin; Lactoperoxidase; Casein Dephosphorylation

\section{Introduction}

Cow Milk Protein Allergy (CMPA) represents the most frequent food allergy in infancy, ranging between 2 and $7.5 \%$ of the infant population. Patients with CMPA often show allergy to other foods including powdered milk containing soy or hydrolyzed proteins [1]. The milk proteins mainly responsible for the allergy are $\alpha$ - and $\beta$-caseins, followed by $\beta$-lactoglobulin and $\alpha$-lactalbumin to a lesser extent [2-4]. In children with CMPA, when it is not possible to breast feed or to use cow milk, the clinical use of donkey milk (DM) is considered [1,5] since several studies have demonstrated the high similarity of DM compared to human milk [6-8]. Furthermore, studies performed using the serum of children with CMPA and milk proteins from other mammalian species evidenced a weak cross-reactivity with milk from donkey [9].

In general, the principal aim of this work is the study of the protein profile of donkey milk. At this purpose the milk was analyzed through two-dimensional electrophoresis (2-DE) followed by $\mathrm{N}$-terminal sequencing, in order to give a panoramic view of the proteins that are present in DM. Particular interest was focused on the casein fractions and on their post-translational modifications (i.e. phosphorylation) that is important since influence the calcium binding ability of caseins. In fact the protein fraction of milk is an important source of bioactive peptides such as casein phosphopeptides that may function as carriers for different minerals [10-12]. Usually these peptides contain a sequence of three phosphoserine and two glutamic acid residues that represents the binding sites for calcium, iron, and zinc therefore playing an important role in mineral bioavailability.

Furthermore, it is well known that caseins may influence the immune system causing allergenic reactions: the phosphoseryl residues of as1-casein and $\beta$-casein may be considered to be immunoreactive and resistant to digestion [13].

The dephosphorylation process in DM casein fraction was performed enzymatically and the dephosphorylated caseins were analyzed by $2-\mathrm{DE}$ in order to investigate the extent of phosphorylation and the molecular changes which occur in caseins during the dephosphorylation process.

Finally, the content of two proteins with antimicrobial activity was determined that could be able to stimulate the development of the neonatal intestine, namely, lactoferrin and lactoperoxidase.

Previously high lysozyme content was found in donkey milk [8] that was supposed to be responsible for the low microbial load found in this milk [6] and could be useful to prevent intestine infections in infants. Lactoferrin may act as an anti-inflammatory protein at local sites of inflammation including the respiratory and gastrointestinal tracts $[14,15]$.

*Corresponding author: Prof. Silvia Vincenzetti, Veterinary School of Medical Sciences, University of Camerino, Road 93/95 Bypass, 62024 Matelica (MC), Italy, Tel: +397373402722; Fax: +397373402727; E-mail: silvia.vincenzetti@unicam.it

Received December 05, 2011; Accepted February 01, 2012; Published February 03, 2012

Citation: Vincenzetti S, Amici A, Pucciarelli S, Vita A, Micozzi D, et al. (2012) A Proteomic Study on Donkey Milk. Biochem Anal Biochem 1:109. doi:10.4172/2161 1009.1000109

Copyright: (c) 2012 Vincenzetti S, et al. This is an open-access article distributed under the terms of the Creative Commons Attribution License, which permits unrestricted use, distribution, and reproduction in any medium, provided the original author and source are credited. 
Lactoperoxidase is a glycoprotein consisting of a single peptide chain with a molecular weight of $78.0 \mathrm{kDa}$. This enzyme exerts its antimicrobial action through the oxidation of thiocyanate ions (SCN) by hydrogen peroxide, both present in biological fluids and also in milk.

We have purified, identified and quantified the lactoferrin from DM using different proteomic approaches: 2-DE, cation exchange chromatography in HPLC followed by SDS-PAGE, N-terminal sequencing and immunoblotting. Furthermore we determined, by a spectrophotometric assay, the concentration and the enzymatic activity of donkey milk lactoperoxidase.

This study on DM proteins may be useful to assess the nutritional characteristics of this milk that is used to feed children affected by CMPA.

\section{Materials and Methods}

\section{Sample milk preparation}

Ten pluriparous donkeys (Ragusana breed) at the third lactation (all the donkeys close to the age of five years) were used to provide milk samples in this study. The serum of the animals used in this study, in order to evaluate their health condition, was examined before the beginning of the experimental trial and was tested negative for brucellosis and equine infectious anemia. Donkeys were manually milked at 40, 60, 80 and 100 days after parturition. Milk samples were frozen at $-20^{\circ} \mathrm{C}$ until analysis. Skimmed milk was prepared by centrifugation at $3000 \mathrm{xg}$ for $30 \mathrm{~min}$ at $15^{\circ} \mathrm{C}$. Whole casein was obtained from skimmed milk by adjusting the $\mathrm{pH}$ to 4.6 with $10 \%(\mathrm{v} / \mathrm{v})$ acetic acid and centrifuging at $3000 \mathrm{xg}$ for $10 \mathrm{~min}$ in order to obtain a supernatant of whey proteins and the isoelectrically precipitated caseins. The caseins were resuspended in $50 \mathrm{mM}$ Tris/ $\mathrm{HCl}, \mathrm{pH} 7.5$; $1 \mathrm{mM}$ DTT and $8 \mathrm{M}$ urea. The protein concentration was determined following the method of Bradford [16], for the casein determination, a blank of 50mM Tris/HCl, pH7.5; 1mM DTT and $8 \mathrm{M}$ urea was used to avoid the interferences of urea with the reagent.

\section{Lactoferrin purification and quantitative determination}

Lactoferrin was purified by cationic exchange chromatography from donkey skimmed milk using a Mono S HR5/5 column, (GEHealthcare, Uppsala, Sweden, $1 \mathrm{ml}$ bed volume) connected to an HPLC system (Äkta Purifier, GE-Healthcare) equilibrated with 50mM ammonium acetate $\mathrm{pH} 5.5$ (buffer A) and eluted by a linear gradient between buffer A and buffer B (1 M ammonium acetate pH 5.5, $1 \mathrm{M}$ $\mathrm{NaCl}$ ), the flow rate was $1.0 \mathrm{ml} / \mathrm{min}$.

The identity of the protein obtained after the chromatographic separation was assured by $12 \%$ sodium dodecyl sulfate polyacrylamide gel electrophoresis (SDS-PAGE) followed by $\mathrm{N}$-terminal sequencing and western blot analysis using polyclonal antibody anti-human lactoferrin (ICL Labs, Newberg, OR, USA). Quantitative determination of lactoferrin from skimmed DM was determined by an HPLC method by using the Mono $S$ column equilibrated and eluted as described above. Each standard solution of human lactoferrin $(20,30,40,60,80$ and 100 final $\mu$ g; GenWay Biotech, Inc. San Diego, CA), was prepared in $50 \mathrm{mM}$ ammonium acetate $\mathrm{pH} 5.5$. An aliquot of each standard solution was separately loaded on the Mono S-HPLC column. The area of each standard peak was measured using the valley-to-valley integration mode and quantification was achieved by a calibration line obtained relating to the concentration in micrograms of each standard loaded onto the column to the peak area corresponding to each lactoferrin

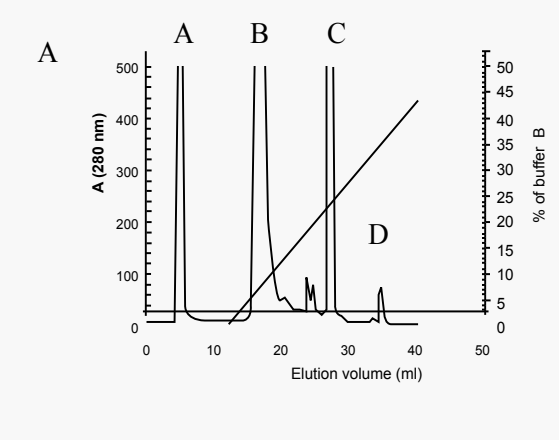

B

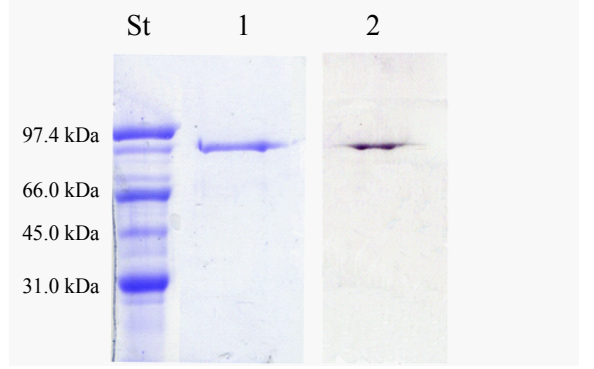

Figure 1: A: Cationic-exchange chromatography on HPLC (Mono S HR 5/5) of the whey protein fraction performed as described in the Materials and Methods section. Lactoferrin was identified in peak D. Other protein identified were: peak A, $\beta$-lactoglobulin; peak B, $\alpha$-lactalbumin, peak C, lysozyme. B. $12 \%$ SDS-PAGE and Immunoblotting. St Bio-Rad low-molecular-weight standard 1) $12 \%$ SDSPAGE of peak $D$ eluted from the Mono $S$ column. 2) Immunoblotting of peak $D$ eluted from the Mono $S$ column by using anti-lactoferrin antibodies.

concentration (Figure 1A). The quantity of lactoferrin was determined by using the calibration line.

\section{Lactoperoxidase activity and quantitative determination}

Lactoperoxidase activity was evaluated by a continuous spectrophotometric rate determination using as substrate 2,2'-Azinobis (3-Ethylbenzthiazoline-6-Sulfonic Acid) (ABTS, Sigma Chemical Co) according to Pruitt and Kamau [17]. The method is based on the reaction: $\mathrm{H}_{2} \mathrm{O}_{2}+$ reduced ABTS $\rightarrow 2 \mathrm{H}_{2} \mathrm{O}+$ oxidized ABTS. The final reaction mix, contained : $75 \mathrm{mM}$ potassium phosphate $\mathrm{pH} 5.5 ; 23 \mathrm{mM}$ ABST; $0.0008 \%(\mathrm{w} / \mathrm{w})$ hydrogen peroxide; the reaction was started by the addition of $10 \mu \mathrm{l}$ of skimmed DM. Absorbance measurements were made at 3 and $5 \mathrm{~min}$, using a $436 \mathrm{~nm}$ wavelength. One unit of lactoperoxidase is defined as the amount of the enzyme that oxidizes $1.0 \mu$ mole of ABST per minute at $\mathrm{pH} 5.5$ and $25^{\circ} \mathrm{C}$. The calculation of the enzymatic activity was made as follows:

Units $/ \mathrm{ml}$ enzyme $=\left(\Delta \mathrm{A}_{436} \mathrm{~nm} / \mathrm{min}\right.$ test- $\Delta \mathrm{A}_{436} \mathrm{~nm} / \mathrm{min}$ blank $) \mathrm{x}($ total $\mathrm{mL}$ of assay)/(29.3) $\mathrm{x}\left(\mathrm{mL}\right.$ of enzyme), were $\mathrm{A}_{436} \mathrm{~nm} / \mathrm{min}$ blank is the absorbance of the potassium phosphate solution with the substrate and the hydrogen peroxide but in absence of milk; 29.3 is the millimolar extinction coefficient of oxidized ABTS at $436 \mathrm{~nm}$.

The peroxidase activity of a standard enzyme solution $\left(\Delta \mathrm{A}_{436} /\right.$ min) was plotted vs each single amount of peroxidase (from 1.0 to 8.0 $\mathrm{ng}$, prepared in $75 \mathrm{mM}$ potassium phosphate $\mathrm{pH} 5.5$ ). The calibration line obtained was used to calculate the concentration of donkey milk lactoperoxidase.

\section{Two-dimensional electrophoresis (2-DE) analysis}

For 2-DE analysis the milk sample was prepared as follows: $100 \mu \mathrm{g}$ 
of whey proteins or $100 \mu \mathrm{g}$ of whole caseins were first cleaned up with a 2-D Clean-Up Kit (GE-Healthcare Life Sciences, Uppsala, Sweden), and then dissolved in a $350 \mu \mathrm{L}$ solution containing: $8 \mathrm{M}$ urea; $2 \%(\mathrm{w} / \mathrm{v})$ 3-[(3-Cholamidopropyl) dimethylammonio]-1-propanesulfonate (CHAPS); $65 \mathrm{mM}$ dithiothreitol (DTT), $0.001 \%$ (w/v) bromophenol blue, $0.5 \%(\mathrm{v} / \mathrm{v})$ IPG buffer ( $\mathrm{pH}$ range $4-7$ for caseins or 3-11 for whey proteins).

Isoelectric focusing (IEF) was performed using a pre-cast immobilized $\mathrm{pH}$ gradient gel strip Immobiline DryStrip, (IPG-strip, length $18 \mathrm{~cm}$ ) with a linear $\mathrm{pH}$ gradient range of 4-7 for caseins and 3-11 for whey proteins. The IPG-strips were placed on IPGphor isoelectric focusing cell (GE- Healthcare) and were rehydrated for 12 hours at $20^{\circ} \mathrm{C}$ without voltage. The focusing was then performed at $20^{\circ} \mathrm{C}$ in 3 steps: in the first step a voltage of $500 \mathrm{~V}$ for one hour was applied, in the second step a voltage of $1000 \mathrm{~V}$ was applied for another hour and in the third step, a voltage of $8000 \mathrm{~V}$ was applied for 4 hours. The current limit per IPG-strip was $50 \mu \mathrm{A}$.

Subsequently, IPG strips were equilibrated for $15 \mathrm{~min}$ in equilibration buffer (50 mM Tris- $\mathrm{HCl}, \mathrm{pH} 8.8 ; 6 \mathrm{M}$ urea; $30 \%$ glycerol; $2 \%$ SDS; $65 \mathrm{mM}$ DTT and a few grains of bromophenol blue) and loaded on $15 \%$ (for whey proteins), 13\% (for caseins), or 7.5\% (for the high-molecular-weight whey proteins) SDS-PAGE, using a Protean II apparatus (Bio-Rad, Hercules, CA, USA). The gels (180 x $200 \times 1.5 \mathrm{~mm}$ ) were run at $30 \mathrm{~mA}$ per gel for 6-7 hours. When the gels were not submitted to electrotransfer, proteins were stained for 1 hour with $0.1 \%$ Coomassie Brilliant Blue R250 (CBB). The gels were de-stained until the protein spots became evident and the gel background transparent. After destaining the gels were scanned, and the gel images were analyzed using PDQuest software (Version 7.1.1; Bio-Rad Laboratories) according to the protocols provided by the manufacturer in order to define spot-intensity calibration, spot detection, background abstraction, calibration, and calculation of molecular mass and pI. The pIs were determined using a linear 4-7 or 3-11 distribution, and molecular mass determinations were based on the markers Bio-Rad low range (phosphorylase b, $97.4 \mathrm{kDa}$; bovine serum albumin, 66.2 kDa; ovalbumin $45.0 \mathrm{kDa}$; carbonic anhydrase, 31 $\mathrm{kDa}$; soybean trypsin inhibitor, $21.5 \mathrm{kDa}$; lysozyme, $14.4 \mathrm{kDa}$ ).

\section{Casein dephosphorylation experiments}

The acid precipitated casein from $25 \mathrm{~mL}$ of fresh DM, prepared as described above, was washed twice in distilled water and resuspended in $10 \mathrm{~mL}$ of $0.4 \%$ ammonium bicarbonate buffer, $\mathrm{pH} 8.5$, containing $0.5 \mathrm{mM} \mathrm{MgCl}$. The solution was heated at $80^{\circ} \mathrm{C}$ for $5 \mathrm{~min}$ in a water bath to aid in dispersion and another $10 \mathrm{~mL}$ buffer was added. The final whole casein solution was divided into aliquots of $1 \mathrm{~mL}$ each containing $5.3 \mathrm{mg}$ casein and lyophilized. Before the dephosphorylation experiments one aliquot of whole casein was resuspended in $1 \mathrm{~mL}$ of CIP buffer (50mM Tris/HCl; $10 \mathrm{mM} \mathrm{MgCl} ; 1 \mathrm{mM}$ DTT, pH7.5). To $100 \mu \mathrm{L}$ of this solution 20 units of Calf Intestinal alkaline Phosphatase (CIP; Calbiochem, La Jolla, CA, USA) was added and the mixture was incubated for 16 hours at $37^{\circ} \mathrm{C}$. After the incubation the sample was frozen at $-20^{\circ} \mathrm{C}$ and lyophilized. Before 2-DE analysis the sample (CIPtreated caseins) was resuspended in rehydration buffer containing IPG buffer, $\mathrm{pH}$ range 4-7. The first dimension (IEF) was performed as described above in the $\mathrm{pH}$ range of 4-7 and the second dimension at $13 \%$ SDS-PAGE. A control sample was prepared using whole casein resuspended in $1 \mathrm{ml}$ of CIP buffer without the addition of the enzyme (CIP) but incubated as described before $\left(16\right.$ hours at $\left.37^{\circ} \mathrm{C}\right)$. This control sample (control caseins) allowed us determine if the experimental incubation conditions affected the molecular characteristics of the casein components. A further control was performed to verify that deamidation reactions occur during 2-DE analysis. In this case, the incubation time with CIP at $37^{\circ} \mathrm{C}$ was reduced to $3 \mathrm{~h}$ and the IEF was performed at lowest temperature [18].

\section{Electrotransfer and $\mathrm{N}$-terminal microsequencing}

After 2-DE, the polyacrylamide gels were equilibrated for $15 \mathrm{~min}$ in 10mM 3-[cyclohexylamino]-1-propanesulfonic acid (CAPS), pH11.0, containing $10 \%(\mathrm{v} / \mathrm{v})$ methanol, before they were electroblotted onto a polyvinylidene difluoride (PVDF) membrane (Sequi-blot; Bio-Rad Laboratories). The blotted proteins were revealed by staining with $0.1 \%(\mathrm{w} / \mathrm{v})$ CBB in $50 \%(\mathrm{v} / \mathrm{v})$ methanol and then the membrane was destained in $50 \%(\mathrm{v} / \mathrm{v})$ methanol.

Electrophoretic spots of interest were excised from the PVDF membrane and the N-terminal aminoacid sequence was determined by Edman degradation using an automatic protein sequencer (Applied Biosystems Procise Model 491 sequencer). The identification of proteins was performed by consulting the NCBI database at http:// blast.ncbi.nlm.nih.gov/, the algorithm used was: BLASTP (proteinprotein blast).

\section{Results and Discussion}

\section{Characterization of donkey milk antimicrobial factors: lactoferrin and lactoperoxidase}

Lactoferrin is an iron-binding protein that displays many biological functions: regulation of iron homeostasis, cellular growth, anti-microbial and anti-viral functions, and protection against cancer development and metastasis [19].

DM lactoferrin was purified by a cationic exchange chromatography (Mono S HR5/5 column) as shown in Figure 1A (peak D). According to the $12 \%$ SDS-PAGE analysis, the purified lactoferrin was judged to be more than $98 \%$ pure (Figure 1B, lane 1) and its identity was confirmed by $\mathrm{N}$-terminal sequencing and by western blot analysis using antilactoferrin antibodies as shown in Figure 1B, lane 2. The other peak eluted from the Mono $S$ column was also identified and resulted to be: peak A, $\beta$-lactoglobulin; peak B, $\alpha$-lactalbumin, peak C, lysozyme. The molecular weight of the protein band corresponding to DM lactoferrin was about $80.0 \mathrm{kDa}$. The quantitative determination of DM lactoferrin (Figure 2A) gave a result of $0.080 \pm 0.0035 \mathrm{~g} / \mathrm{L}$, similar to that found in mare $(0.1 \mathrm{~g} / \mathrm{L})$,cow $(0.02-0.2 \mathrm{~g} / \mathrm{L})$, goat $(0.06-0.40 \mathrm{~g} / \mathrm{L})$, and sheep milk $(0.135 \mathrm{~g} / \mathrm{L})[20,21]$, but lower when compared with the lactoferrin content in human milk (up to $1.0-6.0 \mathrm{~g} / \mathrm{L}$ ) [22].

Lactoperoxidase activity in skimmed DM was very low, $4.83 \pm 0.35$ $\mathrm{mU} / \mathrm{mL}$. The quantification was achieved by a calibration line obtained by plotting the nanograms of peroxidase standard solutions against the $\Delta \mathrm{A}_{436 \mathrm{~nm}} / \mathrm{min}$ as shown in Figure 2B. The mean $( \pm \mathrm{SD})$ concentration of DM lactoperoxidase was calculated to be $0.11 \pm 0.027 \mathrm{mg} / \mathrm{L}$, more than 100 times lower than that of lactoperoxidase activity from bovine milk (0.03-0.1 g/L) [23], but close to the value obtained with human milk $(0.77 \pm 0.38 \mathrm{mg} / \mathrm{L})$ [24]. Several authors reported additive or synergistic antimicrobial effects between these protective factors $[25,26]$. As shown in Table 1, when the concentrations of lactoperoxidase, lactoferrin and lysozyme are compared from bovine, donkey, and human milk, it is clear that human and donkey milk contain considerable amounts of lysozyme and lactoferrin but lactoperoxidase is present only in small amounts. 
Citation: Vincenzetti S, Amici A, Pucciarelli S, Vita A, Micozzi D, et al. (2012) A Proteomic Study on Donkey Milk. Biochem Anal Biochem 1:109. doi:10.4172/2161-1009.1000109

\section{Characterization of donkey milk protein fraction by two- dimensional electrophoresis (2-DE)}

In Figures 3 and 4 the electropherograms are shown for the separation of donkey milk casein fractions (Figure $3 \mathrm{a}$ and $3 \mathrm{~b}$ ) and whey protein fractions (Figure $4 \mathrm{a}, 4 \mathrm{~b}$ and $4 \mathrm{c}$ ). In order to achieve a better separation of the whole casein fractions, we performed the 2-DE analysis in a narrow $\mathrm{pH}$ range of 4-7 for the first dimension and in a $13 \%$ SDS-PAGE for the second dimension. Figure 3 shows about 14 or more major casein spots with molecular mass that are varying from 27.24 to $33.74 \mathrm{kDa}$ and $\mathrm{pI}$ values varying from 4.63 to 5.36 . N-terminal analysis of some of these spots (see Figure 3 and Table 2) revealed mainly the presence of as1- casein and $\beta$-casein as already shown in previous studies $[8,27]$. Nevertheless, Bertino and coworkers [27] also identified in donkey milk the presence of a weak spot identified as $\alpha_{\mathrm{s} 2}$-casein and three very weak spots identified as $k$-casein, whereas Chianese and coworkers [28] detected 11 components for $\kappa$-casein and six phosphorylated components for $\alpha_{\mathrm{s} 1}$-casein.

Donkey milk $\beta$ - caseins showed $\mathrm{pI}$ values ranging from 4.63 to 4.95 , almost close to that found in the equine $\beta$-casein ( $\mathrm{pI}=4.4$ to 5.9 ) but more acidic if compared to human ( $\mathrm{pI}=4.9$ to 5.8 ) and bovine ( $\mathrm{pI}=5.20$ to 5.85$) \beta$-casein [29-31]. In a previous work from other authors [28],

A

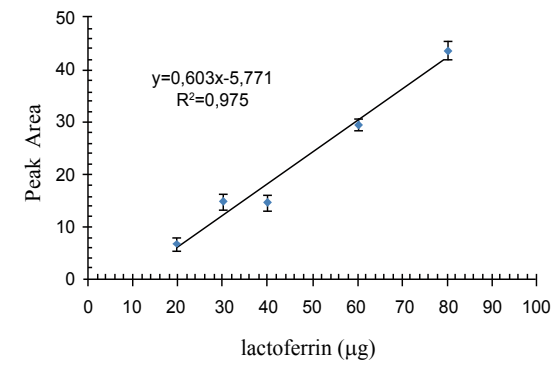

B

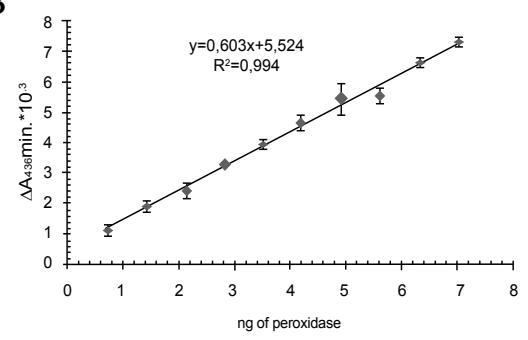

Figure 2: A: Calibration line of standard solutions of lactoferrin (20-100 final $\mu \mathrm{g})$ prepared as described under Material and Methods. Each point was made in triplicate. B: Calibration line obtained by plotting the nanograms of peroxidase standard solutions at different concentration against the $\Delta \mathrm{A}_{436 \mathrm{~mm}} / \mathrm{min}$ (see Materials and Methods). Each point was made in triplicate.

\begin{tabular}{|l|c|c|c|}
\hline Milk & $\begin{array}{c}\text { lactoperoxidase } \\
(\mathrm{mg} / \mathrm{L})\end{array}$ & $\begin{array}{c}\text { Lysozyme } \\
(\mathrm{g} / \mathrm{L})\end{array}$ & $\begin{array}{c}\text { Lactoferrin } \\
(\mathrm{g} / \mathrm{L})\end{array}$ \\
\hline Human & 0,77 & 0.12 & $0.3-4.2$ \\
\hline Donkey & 0.11 & $1.0^{\S}$ & 0.080 \\
\hline Bovine & $30-100$ & trace & 0.10 \\
\hline
\end{tabular}

See references [8, 22-25].

Table 1: Content of lactoperoxidase, lactoferrin and lysozyme from bovine, donkey and human milk.

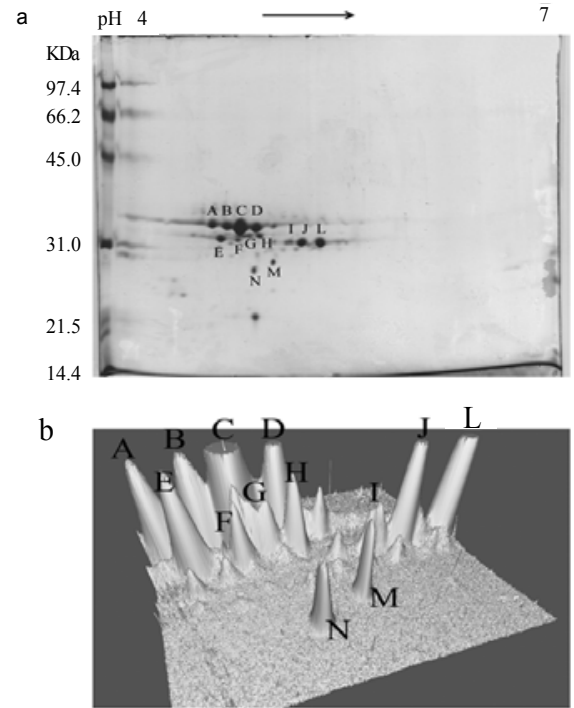

Figure 3: A: 2-DE gel image of casein fraction. Caseins were first separated on an immobilized $\mathrm{pH}$ 4-7 linear gradient strip followed by separation with $13 \%$ SDSPAGE. Gels were stained with Coomassie blue. The standards were Bio-Rad low molecular weight. B: 3D-view of the casein fraction obtained using PDQuest software Version 7.1.1 (Bio-Rad Laboratories).

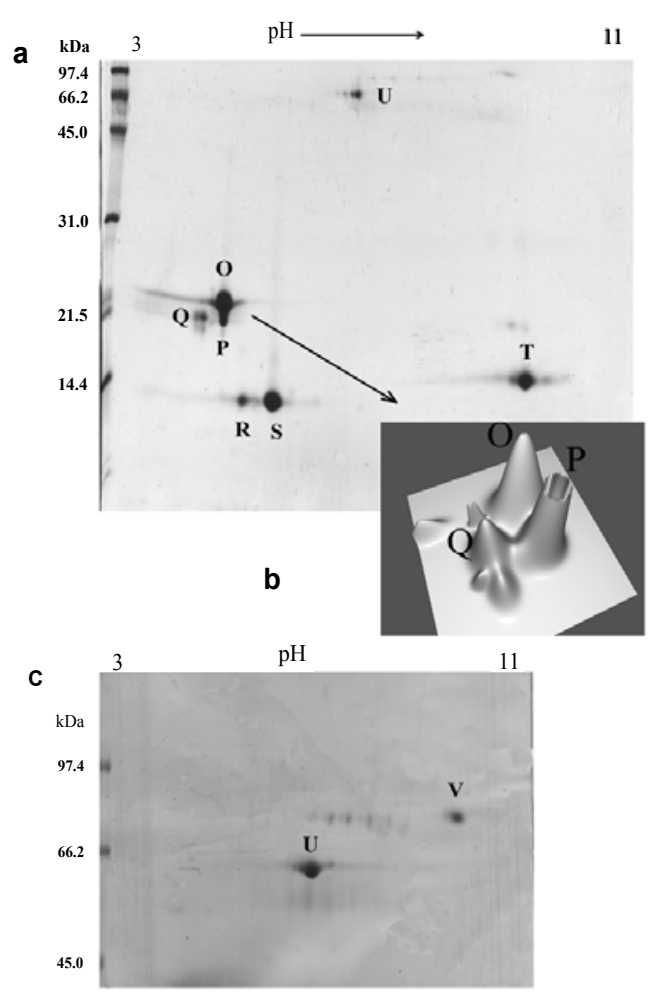

Figure 4: A: 2-DE gel image of low-molecular-weight whey protein fraction separated on an immobilized $\mathrm{pH}$ 3-11 linear gradient strip followed by $15 \%$ SDS-PAGE. The standards were Bio-Rad low molecular weight. B: 3D-view of $\beta$-lactoglobulin obtained using PDQuest software Version 7.1.1 (Bio-Rad Laboratories). C: 2-DE gel image of high-molecular-weight whey protein fraction separated on an immobilized $\mathrm{pH}$ 3-11 linear gradient strip followed by $7.5 \%$ SDS-PAGE. 


\begin{tabular}{|c|c|c|c|c|c|}
\hline spot & $\mathrm{M}_{\mathrm{r}}(\mathrm{kDa})^{\circ}$ & $\mathrm{pl}^{\circ}$ & N-terminal sequence & Protein identification* & Accession no. ${ }^{*}$ \\
\hline A & 33.74 & 4.63 & RKEELNVSS & $\beta$-casein & P86273 (donkey) \\
\hline B & 33.54 & 4.72 & RKEELNVSS & $\beta$-casein & P86273 (donkey) \\
\hline $\mathrm{C}$ & 33.10 & 4.82 & RKEELNVSS & $\beta$-casein & P86273 (donkey) \\
\hline $\mathrm{D}$ & 33.54 & 4,92 & RKEELNVSS & $\beta$-casein & P86273 (donkey) \\
\hline$E$ & 31.66 & 4.68 & RKEELNVSS & $\beta$-casein & P86273 (donkey) \\
\hline $\mathrm{F}$ & 31.48 & 4,80 & RKEELNVSS & $\beta$-casein & P86273 (donkey) \\
\hline G & 32,15 & 4,88 & RKEELNVSS & $\beta$-casein & P86273 (donkey) \\
\hline $\mathrm{H}$ & 31.15 & 4,95 & RKEELNVSS & $\beta$-casein & P86273 (donkey) \\
\hline 1 & 31.20 & 5.15 & RPKLPHRPE & $\alpha_{s 1}$-casein & P86272(donkey) \\
\hline$J$ & 31.14 & 5.23 & RPKLPHRPE & $\alpha_{s 1}$-casein & P86272(donkey) \\
\hline L & 31.14 & 5.36 & RPKLPHRPE & $\alpha_{s 1}$-casein & P86272 (donkey) \\
\hline M & 28.26 & 5.08 & RPKLPHRPE & $\alpha_{s 1}$-casein & P86272 (donkey) \\
\hline $\mathrm{N}$ & 27.24 & 4.92 & RPKLPHRPE & $\alpha_{s 1}$-casein & P86272 (donkey) \\
\hline $\mathrm{O}$ & 21.90 & 4.46 & TNIPQTMQDLDLQEV & $\beta$-lactoglobulin & P13613 (donkey) \\
\hline $\mathrm{P}$ & 20.0 & 4.40 & TNIPQTMQDLDLQEV & $\beta$-lactoglobulin & P13613 (donkey) \\
\hline Q & 20.58 & 4.12 & TNIPQTMQDLDLQEV & $\beta$-lactoglobulin & P13613 (donkey \\
\hline $\mathrm{R}$ & 13.04 & 4.76 & KQFTKHELSQVLKSM & a-lactalbumin & P28546 (donkey) \\
\hline $\mathrm{S}$ & 12.98 & 5.26 & KQFTKHELSQVLKSM & a-lactalbumin & P28546̣donkey) \\
\hline $\mathrm{T}$ & 14.5 & 9.40 & KVFSKHELAHKL & lysozyme & P11375 (donkey) \\
\hline$U$ & 66.3 & 6.62 & DTHKSEIAHRFND & serum albumin & Q5XLE4 (donkey) \\
\hline V & 79.0 & 9.70 & APRKSVRW & lactoferrin & O77811 (horse) \\
\hline
\end{tabular}

Table 2: Characterization of donkey's milk protein fraction spots separated by 2-DE and subsequently stained or transferred on PVDF membranes for N-terminal analysis followed by search in NCBI database.

the presence of two $\beta$-caseins variants were shown. In particular they demonstrated the presence of a full-length $\beta$-casein variant carrying $7,6,5$ phosphate groups, with a $\mathrm{pI}$ of $4.74,4.82,4.91$ respectively and a spliced variant (-923 aminoacids), carrying 7, 6, 5 phosphate groups with a pI of 4.64, 4.72, 4.80 respectively. Looking at table 2 and figure 3 , it may be evinced that the spots $\mathrm{B}, \mathrm{C}$ and $\mathrm{D}$ may correspond to the fulllength forms of $\beta$-caseins (pI: 4.72, 4.82, 4.92 respectively) whereas the spots E, F, and G may correspond to the spliced variants (pI: 4.68, 4.80, 4.88). Chianese et al, [28] found in DM heterogeneity of as1-casein, assigned to either discrete phosphorylation (5, 6 and 7 phosphate/mole) or non-allelic spliced forms. In our work we found in donkey milk five as1-caseins (see table 2): three of them showed a high molecular weight and probably correspond to the full-length phosphorylated forms, whereas two as1- caseins showed a lowest molecular weight therefore they may correspond to the spliced variants.

In conclusion, the heterogeneity shown in the whole casein analysis by $2-\mathrm{DE}$ may be due to a variable degree of phosphorylation and to genetic variants of as1- and $\beta$-caseins [32-34].

The whey fraction was analyzed by $2-\mathrm{DE}$ in a $\mathrm{pH}$ range of $3-11$ for the first dimension and with two different polyacrylamide gel percentages in the second dimension. This allowed a better differentiation and identification of the low- and high-molecular weight whey proteins (see Figure $4 \mathrm{a}$ and $4 \mathrm{c}$, respectively). In particular, Figure 4a illustrates the separation of low-molecular-weight whey proteins achieved by 2-DE (first dimension: IPG-strip, pH 3-11, second dimension: 15\% SDSPAGE); the obtained protein spots were analyzed by PDQuest software and N-terminal sequencing. The result, shown in Table 2, revealed the presence of two isoforms of $a$-lactalbumin (Figure $4 a$, spots $\mathrm{R}$ and S), three isoforms of $\beta$-lactoglobulin (see also Figure $4 \mathrm{a}$ and $4 \mathrm{~b}$, spots $\mathrm{O}, \mathrm{P}$, and $\mathrm{Q}$ ) and lysozyme (Figure $4 \mathrm{a}$, spot $\mathrm{T}$ ). In literature are reported the presence in donkey milk of two donkey milk lysozyme genetic variants named lysozyme A and lysozyme B and a lysozyme B form with an oxidized methionine residue at position 79 , probably arising from chemical modification [35-36].
Regarding $\beta$-lactoglobulin, it is known that in donkey milk, this protein exists under two different forms, named $\beta$-lactoglobulin I, that constitutes the major form (80\%), and $\beta$-lactoglobulin II $[37,38]$ that constitutes the minor form (20\%). Furthermore, Herrouin and coworkers [35] found a genetic variant for $\beta$-lactoglobulin I (named $\beta$-lactoglobulin I B) with amino acid substitutions at positions 97, 150 and 36 explained by the degeneracy of the genetic code, and two genetic variants for $\beta$-lactoglobulin II (named $\beta$-lactoglobulin II B and C). Successively another $\beta$-lactoglobulin II variant (named D) was detected as minor component in the whey fraction of donkey milk [39]. The fact that in our work we observed only three isoforms may be due to the low sensibility of the technique used that probably allowed us to evidence the two major isoforms of $\beta$-lactoglobulin I (A and B) but only one isoform of $\beta$-lactoglobulin II.

$\beta$-lactoglobulin is a protein of the lipocalin family and its high affinity for a wide range of compounds, as well as its significant quantity in milk has opened the way to speculation about its possible physiological function. This protein is involved in hydrophobic ligand transport and uptake, enzyme regulation, and the neonatal acquisition of passive immunity [40]. Recently it was demonstrated that resveratrol, a natural polyphenolic compound with antioxidant activity, interacts with $\beta$-lactoglobulin. The resulting complex increased the photostability and hydrosolubility of resveratrol [41]. The same authors showed that $\beta$-lactoglobulin forms complexes also with folic acid suggesting that these complexes could be used as an effective carrier of folic acid in functional foods [42]. a-lactalbumin concentration in donkey milk is $1.8 \mathrm{mg} / \mathrm{mL}$ [8], very close to human milk. In this work we found two isoforms of $a$-lactalbumin that showed different $\mathrm{pI}$ values. 4.76 and 5.26 .

Two isoforms of a-lactalbumin were also observed by Cunsolo and coworkers [36] who observed oxidized methionine forms for a-lactoalbumin (Met 90), hypothesizing that they arose by in vivo oxidative stresses. Recently, it has been shown that a-lactalbumin presents antiviral, antitumor, and anti-stress properties. In particular 
in human breast milk it was shown that the $\alpha$-lactalbumin-oleic acid complex called HAMLET (Human Alpha-lactalbumin Made LEthal to Tumor cells) is able to induce tumor-selective apoptosis. This complex may be considered as a potential therapeutic agent against various tumor cells $[43,44]$. Other authors [45] have demonstrated the anti-inflammatory activity of $\alpha$-lactalbumin through the inhibition of cyclooxygenase-2 (COX-2) and phospholipase $\mathrm{A}_{2}$ activities.

Figure $4 \mathrm{c}$ shows the electropherogram for the donkey milk highmolecular-weight whey proteins separated by 2 -DE (first dimension: IPG-strip pH 3-11, second dimension: 7.5\% SDS-PAGE). By N-terminal sequencing it was possible to assign the spot $\mathrm{U}$ to serum albumin $(\mathrm{kDa} /$ pI: 62.7/7.1) and the spot $\mathrm{V}$ to lactoferrin (kDa/pI: 77.0/9.8).

\section{Casein dephosphorylation experiments}

Casein dephosphorylation experiments demonstrated that the heterogeneity shown for the donkey casein fractions (Figure 3) is mainly due to post-translational phenomena, in particular to a high degree of phosphorylation. Recently it has been shown that equine $\beta$-casein is phosphorylated at variable degrees resulting in several isoforms carrying up to 7 phosphate groups, more than the bovine and human counterparts [46]. In our work, we performed a study on the prediction of serine, threonine and tyrosine phosphorylation sites, by using the program NetPhos 2.0, available at www.expasy.ch proteomic server [47], in donkey milk as1-casein (Accession No. P86272) and $\beta$-casein (Accession No. P86273).

The phosphorylation sites predicted in the donkey milk $\beta$-casein are: 11 in the serine residues and 1 in threonine and 1 in tyrosine residues, whereas in the as1-casein the predicted phosphorylation sites are: 10 in serine residues and 2 in threonine and 1 in tyrosine residues (data not shown). These phosphorylation studies must be confirmed by further "in vitro" studies, since until now nobody reported phosphorylated tyrosine residues in milk casein fraction.

Figure 5 shows the 2-DE pattern for the whole casein pool incubated without CIP (control caseins, Figure 5a) and dephosphorylation product of caseins (CIP-trated caseins, Figure 5b). The experimental incubation conditions used in this experiment did not affect the molecular characteristics of donkey milk whole caseins, since the 2-DE pattern of the control whole caseins shown in Figure 5a was similar to that of Figure 3. The pattern differences between the control whole casein and the dephosphorylated whole casein reflect the effect of the dephosphorylation process; in particular a shift of the CIP-treated whole casein fraction towards more alkaline values is evident because of the removal of negative charges in the phosphate groups. The dephosphorylated casein fraction (CIP-treated caseins), identified after 2-DE analysis followed by $\mathrm{N}$-terminal sequencing, was compared to the control casein fraction and the results are shown in Table 3. The two distinct spots (A1 and B1) observed in the dephosphorylated whole casein (Figure 5b) are two $\beta$-caseins with similar molecular mass of 33.50 and 32.87, respectively, but different $\mathrm{pI}$ values (5.90 and 6.06 , respectively). The spots $\mathrm{C} 1$ and $\mathrm{I} 1$ resulted from two $\beta$-caseins with similar molecular mass but different $\mathrm{pI}$, whereas the spots D1 and E1, F1, G1, and $\mathrm{H} 1$ are as1-caseins showing different molecular mass and pI values (see Table 3 ). This apparent heterogeneity may be due to non enzymatic deamidation reactions that may occur spontaneously during the prolonged incubation at $37^{\circ} \mathrm{C}$ at basic $\mathrm{pH}$ (the experimental conditions used when casein is treated with CIP) and when IEF is carried out at temperatures above $20^{\circ} \mathrm{C}[20,48]$. Usually, this phenomenon leads to the appearance of one negative charge and

usually occurs at a level of an Asn residue within an Asn-Gly sequence. In fact, the donkey $\beta$-casein sequence contains an Asn-Gly sequence (Asn143-Gly144). In our case, when caseins were dephosphorylated by incubating them with CIP for $3 \mathrm{~h}$ followed by IEF at low temperature a similar electrophoretic pattern of Figure $5 b$ was obtained (data not shown), indicating that no deamidation occurred during the casein dephosphorylation experiments.

From our data it could be assumed that the spots A, B, C, and D (Figure 5a) assigned to $\beta$-caseins were changed, after dephosphorylation, into two distinct spots A1 and B1 (Figure 5b) that showed a similar molecular mass but different pI values (see also Table 3 ).

Presumably the spots $\mathrm{C} 1$ and I1 (Figure 5b and Table 3), characterized by the lowest molecular mass $(31.90 \mathrm{kDa})$, with respect to the two major $\beta$-casein spots $\mathrm{A} 1$ and $\mathrm{B} 1$, may be a dephosphorylated form of a $\beta$-casein splicing variant. In fact, Matéos and coworkers [20] reported in Haflinger mare milk the existence of a $\beta$-casein $\Delta^{5}$ $(30 \mathrm{kDa})$ characterized by a splicing of exon 5 . Furthermore, other

a $\mathrm{pH} 4$

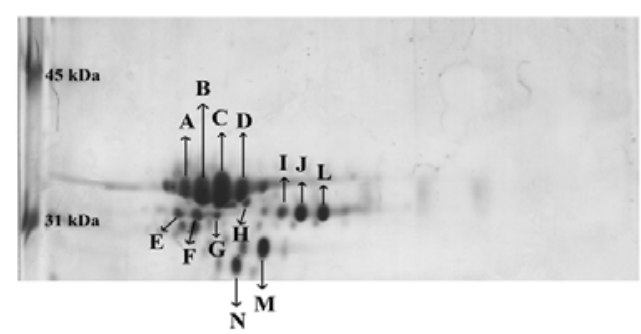

$\mathrm{b}$

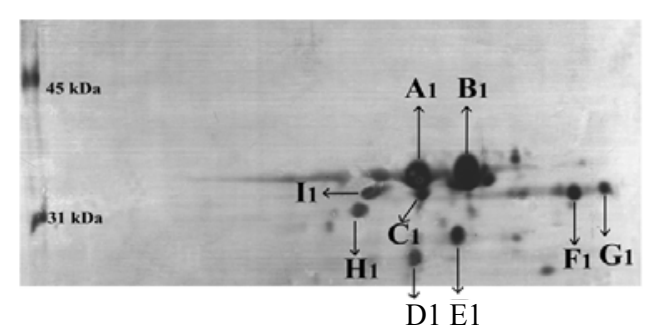

Figure 5: DM casein dephosphorylation performed as described under Materials and Methods: A: Control caseins (not treated with CIP), B: CIPtreated caseins

\begin{tabular}{|c|c|c|c|}
\hline SPOT & $\mathbf{M r}(\mathbf{k D a})^{\circ}$ & $\mathbf{p l}^{\circ}$ & Identification $^{*}$ \\
\hline A1 & 33.50 & 5.90 & $\beta$-casein \\
\hline B1 & 32.87 & 6.06 & $\beta$-casein \\
\hline C1 & 31.90 & 5.92 & $\beta$-casein \\
\hline D1 & 26.80 & 5.88 & $\alpha_{\mathrm{s} 1}$-casein \\
\hline E1 & 28.48 & 6.10 & $\alpha_{\mathrm{s} 1}$-casein \\
\hline F1 & 30.60 & 6.70 & $\alpha_{\mathrm{s} 1}$-casein \\
\hline G1 & 30.60 & 6.86 & $\alpha_{\mathrm{s} 1}$-casein \\
\hline H1 & 30.80 & 5.60 & $\alpha_{\mathrm{s} 1}$-casein \\
\hline I1 & 32.30 & 5.68 & $\beta$-casein \\
\hline
\end{tabular}

- The calculation of experimental pl and molecular mass was carried out using PDQuest software Version 7.1.1 (Bio-Rad Laboratories).

* NCBI BLAST database at http://blast.ncbi.nlm.nih.gov/

Table 3: Donkey milk casein dephosphorylation experiments \& Characterization of the dephosphorylated (CIP-treated) casein fraction. 
authors $[28,49]$ found two donkey $\beta$-casein variants, showing a mass difference of $923 \mathrm{Da}$. These two forms differ for the presence of the domain ${ }_{27}$ SITHINK $_{34}$ in the full-length (variant A) component that, as occurring in the mare's $\beta$-caseins, is absent in the lower Mr protein (variant $\mathrm{A} \Delta^{5}$ ). The same authors [49] demonstrated that the fulllength variant $A$ consists of three isoforms carrying from five to seven phosphate groups, as well as the shorter variant [28]. However in our study we found, after dephosphorylation experiments, four $\beta$-casein spots: A1, B1 (presumably the full length variants); C1 and I1 (the spliced variants). The presence of two forms for each variant (full length and spliced) may be explained by a genetic polymorphism that should be further investigated.

In this study, we found five as1-caseins from donkey milk after dephosphorylation experiments which reflect the five phosphorylated as1-caseins. In particular the spots D1, E1, F1, G1, H1 (dephopsphorylated as1-caseins) correspond to the spots $\mathrm{N}, \mathrm{M}, \mathrm{L}, \mathrm{J}$, I (phosphorylated as1-caseins) respectively. In a previous work other authors [50] evidenced in donkey milk the presence of four major components of as1-casein and two minor components. Of the four major components two of them (A and A1) showed a pentapeptide (HTPRE) insertion that increased the molecular masses of $620 \mathrm{Da}$ with respect to the other two major components B and B1 [50]. Moreover, the absence of the pentapeptide confers to as1-casein variants, $B$ and B1, a more acidic nature. Furthermore the same authors found in donkey milk other two minor as1-casein variants showing higher molecular weight with respect to the major variants [50], but they are present in donkey milk in very small amount.

The present study confirmed the data obtained from the previous cited authors since the spots D1 and E1, that are more acidic and present a lowest molecular mass with respect to the other two spots F1 and G1, may be the two variant without the pentapeptide and consequently the spots F1 and G1 may be presumably the variants with the insertion. We found an additional spot corresponding to a as1-casein (spot H1), which showed a higher molecular mass with respect to the other four spots. The spot H1 may correspond to one of the two minor spots observed by Cunsolo [50], the other minor variant was not observed in this work probably because is present in small amount.

\section{Conclusion}

Milk is an highly nutritious food for both children and adults since it is a source of minerals, vitamins and high quality proteins that possess specific biological properties which make them potential ingredients for human nutrition and promotion of human health. In this work we focused our attention on the protein profile of DM studying it under different aspects. The 2-DE map gave a panoramic view on the protein composition of DM: among caseins were found mainly as1- and $\beta$-caseins that showed a considerable heterogeneity due to variable degree of phosphorylation and to the presence of genetic variants as shown also by other authors [28, 34, 49, 50]. A particular attention was provided on the study of the phosphorylation degree of caseins: the phosphate group of caseins may influence on different characteristics such as their digestion and the mineral bioavailability, but also (in particular the phosphoserine residues) may influence the immunoreactivity of caseins. The risk of allergencity due to specific serine residue phosphorylations observed in bovine milk [13], is actually very low in donkey's milk because, although there are potentially phosphorylated serine residues, it compensates with low amounts of caseins present in this type of milk.
DM whey proteins were analyzed by 2-DE and two of them were also quantified in this milk. From the proteomic map we revealed the presence of two isoforms of a-lactalbumin, three isoforms of $\beta$-lactoglobulin, lysozyme, albumin and lactoferrin. This last protein was also purified at homogeneity by a chromatographic technique and its amount was determined giving a result of $0.080 \pm 0.0035 \mathrm{~g} / \mathrm{L}$. Furthermore the enzymatic activity of lactoperoxidase was determined and also a quantitative determination was performed. The results showed a very low amount of this enzyme in DM.

The results of this study confirmed the nutritional characteristics of the protein fractions of donkey milk and the possibility of using donkey milk in feeding children with cow milk protein allergy (CMPA), including children with multiple food allergies, because of the low amount of caseins.

\section{Acknowledgements}

This research was supported by a grant from the Italian Ministry of Agriculture to the principal researcher, Dr. Paolo Polidori. The authors thank Mrs. Natalina Cammertoni for her excellent technical assistance.

\section{References}

1. Carroccio A, Cavataio F, Montalto G, D'Amico D, Alabrese L, et al. (2000) Intolerance to hydrolysated cow milk proteins in infants: Characteristics and dietary treatment. Clin Exp Allergy 30: 1597-1603.

2. Docena GH, Fernandez R, Chirdo FG, Fossati CA (1996) Identification of casein as the major allergenic and antigenic protein of cow milk. Allergy 51 : 412-416.

3. Bernard H, Créminon C, Yvon M, Wal JM (1998) Specificity of the human IgE response to the different purified caseins in allergy to cow milk proteins. Int Arch Allergy Immunol 115: 235-244.

4. Järvinen KM, Chatchatee P, Bardina L, Beyer K, Sampson HA (2001) IgE and IgG binding epitopes on alpha-lactalbumin and betalactoglobulin in cow milk allergy. Int Arch Allergy Immunol 126: 111-118.

5. Iacono G, Carroccio A, Cavataio F, Montalto G, Soresi M, et al. (1992) Use of ass's milk in multiple food allergy. J Pediatr Gastroenterol Nutr 14: 177-181.

6. Salimei E, Fantuz F, Coppola R, Chiofalo B, Polidori P, et al. (2004) Composition and characteristics of ass's milk. Animal Research 53: 67-78.

7. Monti G, Bertino E, Muratore MC, Coscia A, Cresi F, et al. (2007) Efficacy of donkey milk in treating highly problematic cow milk allergic children: an in vivo and in vitro study. Pediatr Allergy Immunol 18: 258-264.

8. Vincenzetti S, Polidori P, Mariani P, Cammertoni N, Fantuz F, et al. (2008) Donkey milk protein fractions characterization. Food Chem 106: 640-649.

9. Järvinen KM, Chatchatee P (2009) Mammalian milk allergy: clinical suspicion cross-reactivities and diagnosis. Curr Opin Allergy Clin Immunol 9: 251-258.

10. Meisel H, Fitzgerald RJ (2003) Biofunctional peptides from milk proteins: Mineral binding and cytomodulatory effects. Curr Pharm Des 9: 1289-1295.

11. Fitzgerald RJ (1998) Potential uses of caseinophosphopeptides. Int Dairy J 8 : 451-457.

12. Miquel E, Gómez JA, Alegría A, Barberá R, Farré R, et al. (2005) Identification of casein phosphopeptides released after simulated digestion of milk-based infant formulas. J Agric Food Chem 53: 3426-3433.

13. Tezcucano Molina AC, Alli I, Konishi Y, Kermasha S (2007) Effect of dephosphorylation on bovine casein. Food Chem 101: 1263-1271.

14. Kruz ML, Harari,Y, Chen CY, Castro GA (2000) Lactoferrin protects gut mucosal integrity during endotoxemia induced by lipopolysaccharide in mice. Inflammation 24: 33-44.

15. Conneely OM (2001) Anti-inflammatory activities of lactoferrin. J Am Coll Nutr 20: $389-395$

16. Bradford MM (1976) A rapid and sensitive method for the quantitation of microgram quantities of protein utilizing the principle of protein-dye binding Anal Biochem 72: 249-254. 
Citation: Vincenzetti S, Amici A, Pucciarelli S, Vita A, Micozzi D, et al. (2012) A Proteomic Study on Donkey Milk. Biochem Anal Biochem 1:109. doi:10.4172/2161-1009.1000109

Page 8 of 8

17. Pruitt KM, Kamau DN (1994) Quantitative analysis of bovine lactoperoxidase system components and of the effects of the activated system on bacterial growth and survival. In: Indigenous Antimicrobial Agents of Milk. International Dairy Federation Brussels, Belgium, 73-87.

18. Matéos A, Girardet JM, Mollé D, Dary A, Miclo L, et al. (2009) Twodimensional cartography of equine $\beta$-casein variants achieved by isolation of phosphorylation isoforms and control of the deamidation phenomenon. J Dairy Sci 92: 2389-2399.

19. Ward PP, Paz E, Conneely OM (2005) Multifunctional roles of lactoferrin: a critical overview. Cell Mol Life Sci 62: 2540-2548.

20. Matéos A, Girardet JM, Mollé D, Dary A, Miclo L, et al. (2009) Twodimensional cartography of equine $\beta$-casein variants achieved by isolation of phosphorylation isoforms and control of the deamidation phenomenon. J Dairy Sci 92: 2389-2399.

21. Hennart PF, Brasseu DJ, Delogne-Desnoeck JB, Dramaix MM, Robyn CE (1991) Lysozyme, lactoferrin, and secretory immunoglobulin A content in breast milk: Influence of duration of lactation, nutrition status, prolactin status, and parity of mother. Am J Clin Nutr 53: 32-39.

22. Kanyshkova TG, Buneva VN, Nevinsky GA (2001) Lactoferrin and its biological functions. Biochemistry (Moscow) 66: 1-7.

23. Janet RL, Tanaka $T$ (2007) Antimicrobial activity of lactoferrin and lactoperoxidase in milk. In: Dietary protein research trends. Nova Science Publisher, New York, 101-115.

24. Shin K, Hayasawa H, Lönnerdal B (2001) Purification and quantification of lactoperoxidase in human milk with use of immunoadsorbent with antibodies against recombinant human lactoperoxidase. Am J Clin Nutr 73: 984-989.

25. Tenovuo J, Moldoveanu Z, Mestecky J, Pruitt KM, Rahemtulla BM (1982) Interaction of specific and innate factors of immunity: IgA enhances the antimicrobial effect of the lactoperoxidase system against Streptococcus mutans. J Immunol 128: 726-731.

26. Arnold R, Russell JE, Devine SM, Adamson M, Pruitt KM (1984) Antimicrobia activity of the secretory innate defense factors lactoferrin, lactoperoxidase and lysozyme. In: Cardiology Today. B Guggenheim, Basel, Switzerland, Karger. 75-88.

27. Bertino E, Gastaldi D, Monti G, Baro C, Fortunato D, et al. (2010) Detailed proteomic analysis on DM: insight into its hypoallergenicity. Front Biosci 2: 526 536.

28. Chianese L, Calabrese MG, Ferranti P, Mauriello R, Garro G, et al. (2010) Proteomic characterization of donkey milk "caseome". J Chromatogr A 1217: 4834-4840.

29. Egito AS, Miclo L, Lopez C, Adam A, Girardet JM, et al. (2002) Separation and characterization of mare's milk as1-, $\beta$-, $\mathrm{k}$-casein, $\mathrm{y}$-casein-like, and proteose peptone component 5-like peptides. J Dairy Sci 85: 697-706.

30. Poth AG, Deeth HC, Alewood PF, Holland JW (2008) Analysis of the human casein phosphoproteome by 2-D electrophoresis and MALDI-TOF/TOF MS reveals new phosphoforms. J Proteome Res 7: 5017-5027.

31. Belitz HD, Grosch W, Schieberle P (2009) Food Chemistry. (4th edn), Springer Verlag Berlin Heidelberg.

32. Visser S, Jenness R, Mullin RJ (1982) Isolation and characterization of $\beta$ - and Y-caseins from horse milk. Biochem J 203: 131-139.

33. Ochirkhuyag B, Chobert JM, Dalgarrondo M, Haertlè T (2000) Characterization of mare caseins. Identification of as1- and as2-caseins. Lait 80: 223-235.

34. Criscione A, Cunsolo V, Bordonaro S, Guastella AM, Saletti R, et al. (2009) Donkey milk protein fraction investigated by electrophoretic methods and mass spectrometry analysis. Int Dairy J 19: 190-197.

35. Herrouin M, Molle D, Fauquant J, Ballestra F, Maubois JL, Leonil J. (2000) New Genetic Variants Identified in Donkey's Milk Whey Proteins. J Protein Chem 19: $105-115$

36. Cunsolo V, Saletti R, Muccilli V, Foti S (2007) Characterization of the protein profile of donkey's milk whey fraction. J Mass Spectrom 42: 1162-1174.

37. Godovac-Zimmermann J, Conti A, James L, Napolitano L (1988) Microanalysis of the amino-acid sequence of monomeric beta-lactoglobulin I from donkey
(Equus asinus) milk. The primary structure and its homology with a superfamily of hydrophobic molecule transporters. Biol Chem Hoppe-Seyler 369: 171-179.

38. Godovac-Zimmermann J, Conti A, Sheil M, Napolitano L. (1990) Covalent structure of the minor monomeric beta-lactoglobulin II component from donkey milk. Biol Chem Hoppe-Seyler 371: 871-879.

39. Cunsolo V, Costa A, Saletti R, Muccilli V, Foti S. (2007). Detection and sequence determination of a new variant $\beta$-lactoglobulin II from donkey. Rapid Commun Mass Spectrom. 21: 1438-1446.

40. Kontopidis G, Holt C, Sawyer, L (2004) $\beta$-Lactoglobulin: Binding Properties, Structure, and Function. J Dairy Sci 87: 785-796.

41. Liang L, Tajmir-Riahi HA, Subirade M (2008) Interaction of beta-lactoglobulin with resveratrol and its biological implications. Biomacromolecules 9: 50-6.

42. Liang L, Subirade M (2010) beta-Lactoglobulin/Folic Acid Complexes: Formation, Characterization, and Biological Implication. J Phys Chem B 114 6707-6712.

43. Hallgren O, Aits S, Brest P, Gustafsson L, Mossberg AK, et al. (2008) Apoptosis and tumor cell death in response to HAMLET (human alpha-lactalbumin made lethal to tumor cells). Adv Exp Med Biol 606: 217-40.

44. Zhang M, Yang F Jr, Yang F, Chen J, Zheng CY, et al. (2009) Cytotoxic aggregates of alpha-lactalbumin induced by unsaturated fatty acid induce apoptosis in tumor cells. Chem Biol Interact 180: 131-42.

45. Yamaguchi M, Yoshida K, Uchida M (2009) Novel functions of bovine milkderived alpha-lactalbumin: anti-nociceptive and anti-inflammatory activity caused by inhibiting cyclooxygenase-2 and phospholipase A2. Biol Pharm Bull 32: 366-371.

46. Matéos A, Girardet JM, Mollé D, Corbier C, Gaillard JL, et al. (2010) Identification of phosphorylation sites of equine beta-casein isoforms. Rapid Commun Mass Spectrom 24: 1533-1542.

47. Blom N, Gammeltoft S, Brunak S (1999) Sequence and structure-based prediction of eukaryotic protein phosphorylation sites. J Mol Biol 294: 13511362.

48. Girardet JM, Miclo L, Florent S, Mollé D, Gaillard JL (2006) Determination of the phosphorylation level and deamidation susceptibility of equine $\beta$-casein. Proteomics 6: 3707-3717.

49. Cunsolo V, Cairone E, Saletti R, Muccilli V, Foti S (2009) Sequence and phosphorylation level determination of two donkey $\beta$-caseins by mass spectrometry. Rapid Commun Mass Spectrom 23: 1907-1916.

50. Cunsolo V, Cairone E, Fontanini D, Criscione A, Muccilli V, et al. (2009) Sequence determination of alphas1-casein isoforms from donkey by mass spectrometric methods. J Mass Spectrom 44: 1742-1753. 